\title{
Diurnal Patterns of Blood Glucose, Serum Free Fatty Acids, Insulin, Glucagon and Growth Hormone in Normals and Juvenile Diabetics
}

\author{
Aa.P. Hansen and K. Johansen \\ Second University Clinic of Internal Medicine, Kommunehospitalet, Aarhus, Denmark
}

Received: April 17, 1969

\begin{abstract}
Summary. Blood glucose, serum free fatty acids, -insulin, -glucagon and -growth hormone have been measured half-hourly in five newly diagnosed, untreated, male patients with classic juvenile diabetes and in five healthy male subjects during a $24-\mathrm{h}$ period of daily life. - Blood glucose, serum insulin and -free fatty acids followed, on the whole, the expected pattern. Serum glucagon showed a fairly constant level during day and night in both groups. - In the non-diabetic subjects, serum growth hormone was low during most of the day. Only two peaks were ob. served before $10 \mathrm{p} . \mathrm{m}$. Four of the subjects showed peaks at precisely the same time, namely at $10.30 \mathrm{p.m}$. and $1.30 \mathrm{a} . \mathrm{m}$. Two showed peaks at $5.00-5.30 \mathrm{p.m}$. The mean serum growth hormone concentration during the 24-h period was $1.98 \mathrm{ng} / \mathrm{ml}$. - In the juvenile diabetics, the growth hormone was higher and the level fluctuated much more, showing more frequent and higher peaks than in the non-diabetics. The mean serum growth hormone concentration during the 24 -h period was $7.26 \mathrm{ng} / \mathrm{ml}$, i.e. three to four times higher than in the non-diabetics.
\end{abstract}

Schéma d'évolution de la glycémie, des acides gras libres, de l'insuline, du glucagon et de l'hormone de croissance dans le sérum, chez des sujets normaux et des diabétiques juvéniles

Résumé. La glycémie, les acides gras libres, l'insuline, le glucagon et l'hormone de croissance sériques ont été mesurés toutes les demi-heures chez cinq patients de sexe masculin, atteints de diabète juvénile classique, récemment diagnostiqué et non traité, et chez cinq sujets de sexe masculin en bonne santé pendant une période de $24 \mathrm{~h}$. La glycémie, l'insuline et les acides giras libres du sérum suivaient dans l'ensemble le schéma attendu. Le taux de glucagon sérique était assez constant pendant le jour et la nuit dans les deux groupes. - Chez les sujets nondiabétiques, l'hormone de croissance du sérum était basse pendant la plus grande partie du jour. Deux pies seulement ont été observés avant $10 \mathrm{~h}$ du soir. Quatre des sujets ont eu des valeurs élevées exactement au même moment, c'est-à-dire à $10.30 \mathrm{~h}$ du soir et à $1.30 \mathrm{~h}$ du matin. Deux ont eu des valeurs élevées à $5 \mathrm{~h}-5.30 \mathrm{~h}$ de l'après-midi. La concentration moyenne d'hormone de croissance du sérum pendant la période de $24 \mathrm{~h}$ était de $1.98 \mathrm{ng} / \mathrm{ml}$. Chez les diabétiques juvéniles, l'hormone de croissance était plus élevée et le taux variait beaucoup plus, mont. trant des pics plus fréquents et plus élevés que chez les non-diabétiques. La concentration moyenne d'hormone de croissance du sérum pendant la période de $24 \mathrm{~h}$ était de $7.26 \mathrm{ng} / \mathrm{ml}$, c'est-à-dire une concentration trois à quatre fois plus élevée que chez les non-diabétiques.

Tagesrhythmen des Blutzuckers und der Serumspiegel der freien Fettsäuren, des Insulins, des Glucagons und des Wachstumshormons bei Normalpersonen und jugendlichen Diabetikern

Zusammenfassung. Bei gesunden Männern und 5 männlichen Patienten mit dem klassischen Bild eines frisch entdeckten, unbehandelten, jugendlichen Diabetes wurden in halbstündigen Abständen der Blutzucker und die Spiegel der freien Fettsäuren, des Insulins, des Glucagons und des Wachstumshormons im Serum während einer 24 Std-Periode des Tagesablaufs bestimmt. - Die Tageskurven für Blutzucker, freie Fettsäuren und Seruminsulin zeigten dabei im ganzen den erwarteten Verlauf. Das Serumglucagon wies in beiden Gruppen bei Tag und Nacht recht konstante Werte auf. - Bei den Normalpersonen fanden sich den größten Teil des Tages niedrige Wachstumshormon-Spiegel. Nur 2 Gipfel wurden vor 22 Uhr beobachtet. $4 \%$ der Kontrollpersonen zeigten solche Maxima genau gleichzeitig, nämlich um 22.30 und um 1.30 Uhr. Bei 2 ließen sich Gipfel um $17 \mathrm{Uhr}$ und 17.30 nachweisen. Die durchschnittliche WachstumshormonKonzentration während der 24 Std-Periode betrug 1.9.Bei den jugendlichen Diabetikern lagen die Werte für das Wachstumshormon höher, schwankten stärker und zeigten mehr und höhere Gipfel als bei den nichtdiabetischen Vergleichspersonen. Der mittlere WachstumshormonSpiegel betrug während der 24 Std-Periode $7.26 \mathrm{ng} / \mathrm{ml}$, lag also $3-4 \times$ höher als beim Kontrollkollektiv.

Key-words: Serum growth hormone, serum insulin, serum glucagon, serum free fatty acids, blood glucose, juvenile diabetes, diurnal patterns.
Current knowledge of endocrine factors concerning glucose homeostasis and its disturbance in diabetics is derived mainly from studies employing loading with glucose, amino acids or other compounds, or after the administration of various hormones. A few reports have also appeared discussing blood glucose homeostasis on the basis of experiments with "isolated" tissue, especially in forearm studies [4]. It is, however, often difficult to interpret results obtained in loading studies, particularly in studies of "isolated" tissue, in terms of overall homeostasis.

It seemed of interest, therefore, to endeavour to elucidate the blood glucose regulation as it actually occurs during daily life, by following a series of relevant parameters at short intervals during a 24 -hour period.

The present report describes the 24 -h pattern of blood glucose, serum free fatty acids, -insulin, -glucagon and -growth hormone in young patients with untreated, classic juvenile diabetes.

\section{Methods}

Five newly-diagnosed, untreated, male patients with classic juvenile diabetes were examined. Their mean age was 17 years (range $10-22$ ). Five healthy, male students served as control subjects. Their mean age was 26 years (range $25-28$ ). None of the subjects 
were obese. The five healthy controls came to the hospital in the morning half an hour before the start of the experiments. The five diabetics were examined during admission to the hospital. Only one of the diabetics (No. 2 from above in Fig. 4) was ketotic during the experiment, with plasma total $\mathrm{CO}_{2}$ between 16 and $12 \mathrm{mEq} / \mathrm{l}$. All the subjects had been fasting 10 to $12 \mathrm{~h}$ before the beginning of the experiment at $8.30 \mathrm{a} . \mathrm{m}$. An indwelling catheter was inserted into an antecubital

Table 1. Time-table for the 24-h period of "daily life"

a.m.

$\begin{array}{cccr}8.30-9.00 & \text { Breakfast containing protein } & \mathrm{g} & 6 \\ & \text { carbohydrate } & \mathrm{g} & 65 \\ & \text { lipid } & \mathrm{g} & 17 \\ & \text { calories } & & 453\end{array}$

$9.00-9.10$ One cigarette

$10.30-11.00$ One cigarette, and

one beer containing carbohydrate $g \quad g$ $\begin{array}{llr}\text { alcohol } & \mathbf{1 2}\end{array}$

p.m.

12.15-12.30 Lunch containing protein g 24 carbohydrate $g \quad 44$ $\begin{array}{lll}\text { lipid } & g & 28\end{array}$ calories $\quad 538$

12.30-12.45 One cigarette

$1.00-1.30$ One beer

$3.00-4.00$ Two cups of coffee without sugar, cream or milk. One cigarette.

$5.30-6.00$ Dinner containing

$\begin{array}{lrr}\text { protein } & g & 16 \\ \text { carbohydrate } & \mathrm{g} & \mathbf{1 2 3} \\ \text { lipid } & \mathrm{g} & \mathbf{2 8} \\ \text { calories } & & \mathbf{8 3 0}\end{array}$

$6.00-6.30$ One cigarette and one beer

$8.30-9.30$ Gentle walk

$10.30-11.00$ One cigarette and one beer

$12.00-$

Sleep period.

vein, and blood samples were drawn every half hour during a 24-h period of "daily life" (Table 1). The subjects were ambulant during the day-time. They stayed in a room, reading, talking or listening to the radio, except for short walks on the same floor. 3 meals were served: at 8.30 a.m., $12.15 \mathrm{p} . \mathrm{m}$. and $5.30 \mathrm{p.m}$. No other food or sweets was allowed except a drink of beer as indicated in Table 1 . From $8.30-9.30$ p.m. the subjects went for a gentle walk in the hospital grounds before retiring to sleep at 12 midnight.

The blood samples were centrifuged and stored at $-20^{\circ} \mathrm{C}$ until analysis. Blood glucose was measured by a glucose oxidase method [3], and serum free fatty acids were determined by a colorimetric method [13]. Serum insulin was measured by a double-antibody radioimmunoassay [7] with EDTA addition. Serum growth hormone was measured by a single-antibody radioimmunoassay [15], using a Wilhelmi preparation as standard. Serum glucagon was determined by a singleantibody radioimmunoassay [15] in three of the controls and two of the diabetics. With this method it is not possible to distinguish between gut and pancreatic glucagon.

\section{Non-diabetics}

\section{Results}

The results in the five control subjects are seen in Table 2, 3 and Fig. 1.

Blood glucose and serum insulin levels rose after eating and fell shortly thereafter. Serum free fatty acids fell after eating, rose in the late noon and during the evening, and remained high during the night. Serum glucagon showed a constant level during day

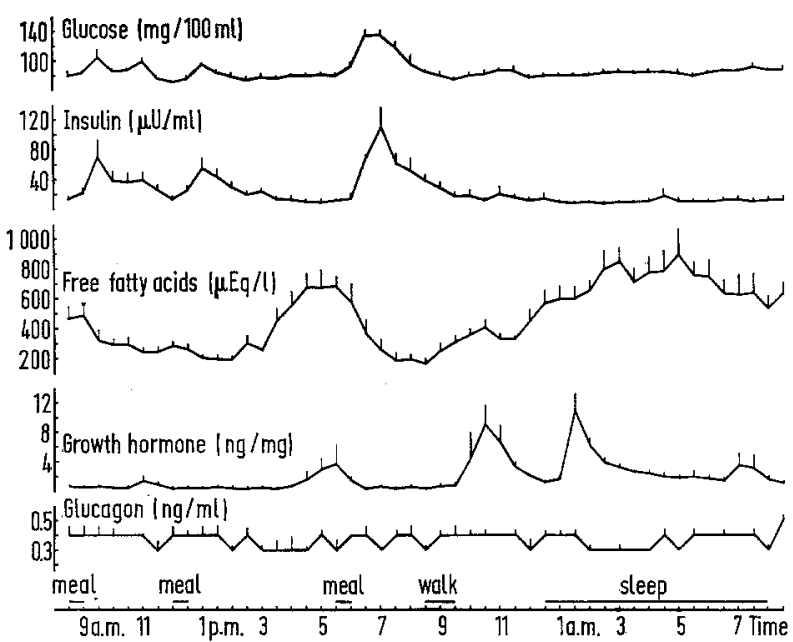

Fig. 1. Average curves of blood glucose, serum insulin, -free fatty acids, -growth hormone and -glucagon in five healthy males. Mean values + S.E.M.

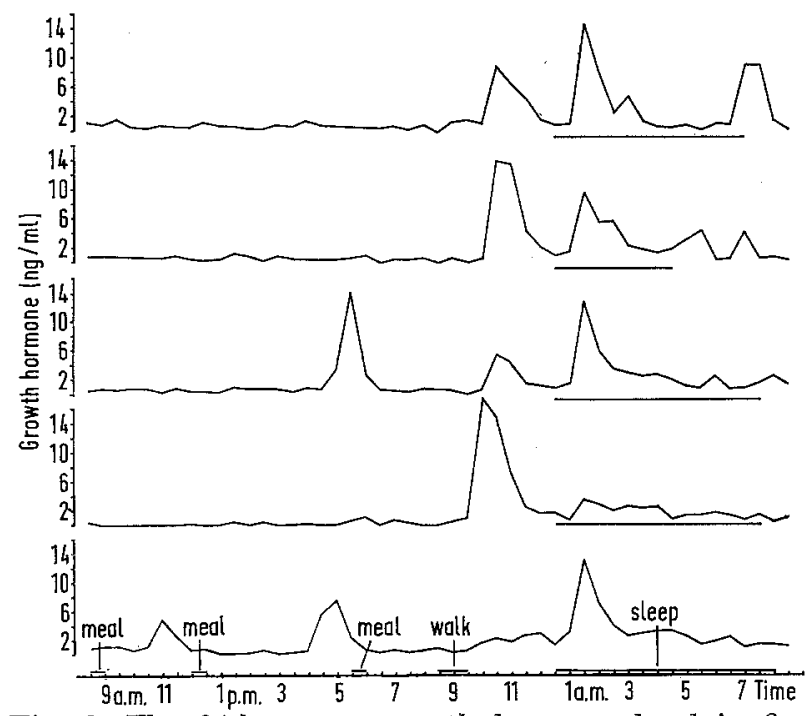

Fig. 2. The 24-h serum growth hormone level in five healthy males

and night. Serum growth hormone was low during most of the day. Only two growth hormone peaks (>5 ng/ $\mathrm{ml}$ ) were observed before $10 \mathrm{p} . \mathrm{m}$. (Fig. 2). Four of the subjects showed peaks at precisely the same time, namely at $10.30 \mathrm{p.m}$. and $1.30 \mathrm{a.m}$., and two showed peaks at $5-5.30$ p.m. Together the five control subjects exhibited 11 growth hormone peaks. 
Diabetics

The results from the five juvenile diabetics are seen in Table 3, 4 and Fig. 3 .

Blood glucose rose after the meals, but to a much higher level than in the normal subjects and it fell fatty acid level during the 24-h period was twice as high as in the controls, and the meal-related falls and rises seen in the controls were hardly discernable. The serum glucagon level was fairly constant during the day, and fell to a lower level during the night. The

Table 2. The 24-h level of blood glucose, serum insulin, -glucagon and free fatty acids in five normal subjects. (Mean \pm S.E.M.)

\begin{tabular}{|c|c|c|c|c|c|c|c|c|}
\hline \multirow[t]{2}{*}{ Time } & \multicolumn{2}{|c|}{$\begin{array}{l}\text { Glucose } \\
\mathrm{mg} / 100 \mathrm{ml}\end{array}$} & \multicolumn{2}{|c|}{$\begin{array}{l}\text { Insulin } \\
\mu \mathrm{U} / \mathrm{ml}\end{array}$} & \multicolumn{2}{|c|}{$\begin{array}{l}\text { Glucagon } \\
\mathrm{ng} / \mathrm{ml}\end{array}$} & \multicolumn{2}{|c|}{$\begin{array}{l}\text { Free fatty acids } \\
\mu \mathrm{Eq} / \mathrm{l}\end{array}$} \\
\hline & Mean & S.E.M. & Mean & S.E.M. & Mean & S.E.M. & Mean & S.E.M. \\
\hline & 81 & 5.5 & 15 & 4.3 & 0.4 & 0.06 & 470 & 80 \\
\hline \multirow{2}{*}{9 a.m. } & 85 & 3.2 & 23 & 5.5 & 0.4 & 0.06 & 490 & 93 \\
\hline & 105 & 11.1 & 70 & 24.0 & 0.4 & 0.06 & 320 & 77 \\
\hline \multirow[t]{2}{*}{10} & 87 & 3.1 & 39 & 10.7 & 0.4 & 0.07 & 290 & 38 \\
\hline & 88 & 4.1 & 37 & 10.7 & 0.4 & 0.03 & 290 & 51 \\
\hline \multirow{2}{*}{11} & 99 & 6.3 & 39 & 11.5 & 0.4 & 0.03 & 240 & 34 \\
\hline & 76 & 5.1 & 26 & 5.9 & 0.3 & 0.03 & 240 & 29 \\
\hline \multirow[t]{2}{*}{12} & 71 & 2.5 & 13 & 4.5 & 0.4 & 0.06 & 280 & 31 \\
\hline & 76 & 2.8 & 25 & 7.1 & 0.4 & 0.03 & 260 & 31 \\
\hline \multirow{2}{*}{1 p.m. } & 94 & 4.0 & 54 & 13.8 & 0.4 & 0.06 & 200 & 15 \\
\hline & 83 & 4.5 & 43 & 10.8 & 0.4 & 0.06 & 190 & 26 \\
\hline \multirow[t]{2}{*}{2} & 78 & 5.2 & 29 & 7.3 & 0.3 & 0.03 & 190 & 17 \\
\hline & 74 & 5.8 & 19 & 4.7 & 0.4 & 0.05 & 300 & 51 \\
\hline \multirow[t]{2}{*}{3} & 77 & 4.5 & 23 & 3.5 & 0.3 & 0.03 & 250 & 80 \\
\hline & 75 & 4.3 & 13 & 2.9 & 0.3 & 0.06 & 440 & 87 \\
\hline \multirow[t]{2}{*}{4} & 79 & 2.0 & 12 & 4.7 & 0.3 & 0.09 & 550 & 85 \\
\hline & 79 & 3.1 & 9 & 2.7 & 0.3 & 0.03 & 670 & 91 \\
\hline \multirow[t]{2}{*}{5} & 80 & 3.4 & 8 & 3.3 & 0.4 & 0.03 & 670 & 110 \\
\hline & 78 & 2.3 & 10 & 3.2 & 0.3 & 0.07 & 680 & 62 \\
\hline \multirow[t]{2}{*}{6} & 91 & 4.0 & 13 & 4.7 & 0.4 & 0.00 & 570 & 118 \\
\hline & 132 & 7.3 & 67 & 3.7 & 0.4 & 0.06 & 360 & 87 \\
\hline \multirow[t]{2}{*}{7} & 133 & 6.0 & 109 & 26.0 & 0.3 & 0.00 & 250 & 68 \\
\hline & 116 & 8.0 & 60 & 12.9 & 0.4 & 0.03 & 180 & 50 \\
\hline \multirow[t]{2}{*}{8} & 94 & 9.8 & 50 & 15.7 & 0.4 & 0.06 & 190 & 25 \\
\hline & 84 & 2.4 & 36 & 9.3 & 0.3 & 0.03 & 160 & 25 \\
\hline \multirow[t]{2}{*}{9} & 78 & 4.5 & 27 & 7.1 & 0.4 & 0.03 & 240 & 47 \\
\hline & 74 & 2.2 & 16 & 5.6 & 0.4 & 0.06 & 300 & 39 \\
\hline \multirow[t]{2}{*}{10} & 79 & 4.0 & 16 & 7.2 & 0.4 & 0.03 & 350 & 38 \\
\hline & 80 & 4.6 & 10 & 3.3 & 0.4 & 0.03 & 400 & 48 \\
\hline 11 & 85 & 3.4 & 18 & 9.4 & 0.4 & 0.00 & 320 & 39 \\
\hline & 85 & 5.2 & 14 & 4.1 & 0.4 & 0.03 & 320 & 21 \\
\hline 12 & 76 & 3.9 & 9 & 5.0 & 0.3 & 0.07 & 440 & 81 \\
\hline & 78 & 2.8 & 12 & 6.6 & 0.4 & 0.03 & 560 & 76 \\
\hline 1 a.m. & 78 & 3.9 & 7 & 3.4 & 0.4 & 0.03 & 590 & 88 \\
\hline & 78 & 3.4 & 6 & 2.2 & 0.4 & 0.03 & 590 & 83 \\
\hline 2 & 78 & 3.3 & 7 & 2.2 & 0.3 & 0.03 & 640 & 75 \\
\hline & 81 & 4.0 & 5 & 2.9 & 0.3 & 0.00 & 790 & 125 \\
\hline 3 & 83 & 3.3 & 7 & 3.0 & 0.3 & 0.03 & 830 & 105 \\
\hline & 81 & 2.5 & 7 & 2.6 & 0.3 & 0.00 & 700 & 88 \\
\hline 4 & 82 & 2.7 & 8 & 3.5 & 0.3 & 0.00 & 760 & 113 \\
\hline & 82 & 2.1 & 15 & 7.9 & 0.4 & 0.03 & 770 & 136 \\
\hline 5 & 80 & 4.9 & 10 & 4.2 & 0.3 & 0.00 & 880 & 174 \\
\hline & 76 & 3.6 & 7 & 2.6 & 0.4 & 0.03 & 740 & 88 \\
\hline 6 & 80 & 2.9 & 7 & 3.0 & 0.4 & 0.00 & 730 & 106 \\
\hline & 83 & 2.8 & 9 & 3.3 & 0.4 & 0.03 & 620 & 92 \\
\hline 7 & 82 & 3.3 & 10 & 4.2 & 0.4 & 0.00 & 610 & 133 \\
\hline & 87 & 4.7 & 7 & 3.2 & 0.4 & 0.03 & 620 & 126 \\
\hline 8 & 83 & 2.6 & 9 & 3.4 & 0.3 & 0.03 & 520 & 76 \\
\hline & 83 & 4.1 & 9 & 4.8 & 0.5 & 0.03 & 620 & 72 \\
\hline
\end{tabular}

more slowly. The fasting level was not reached during the day-time but only at $3-4$ a.m. Serum insulin remained constantly low throughout the day and night in three of the patients. In the other two a significant rise was seen at $9.30-10.00$ p.m. Serum free fatty acid levels fluctuated much more, and the mean serum free growth hormone values throughout the 24 -h period were higher in the diabetics than in the non-diabetics (Fig. 4). Moreover, the growth hormone pattern in the diabetics was characterized by more frequent and higher peaks. The fasting serum growth hormone was $9.0 \pm 2.94 \mathrm{ng} / \mathrm{ml}$ (mean $\pm \mathrm{SEM}$ ) in the juvenile dia- 
beties, and $0.7 \pm 0.15 \mathrm{ng} / \mathrm{ml}$ (mean $\pm \mathrm{SEM}$ ) in the nondiabetics. The mean serum growth hormone level during the $24 \mathrm{~h}$ (Fig. 5) was $7.26 \mathrm{ng} / \mathrm{ml}$ in the juvenile diabetics and $1.98 \mathrm{ng} / \mathrm{ml}$ in the non-diabetics, i.e. the diurnal growth hormone level was 3-4 times higher in the diabetics.
The serum insulin also varied as could be anticipated from earlier loading studies and 24 -h studies. It rose immediately in relation to the rises in the blood glucose in the non-diabetic subjects, and the rise was proportional to the blood glucose elevations.

In the juvenile-diabetic subjects, the serum insulin

Table 3. The 24-h values of serum growth hormone $(\mathrm{ng} / \mathrm{ml})$ in five normal subjects and in five juvenile diabetics

\begin{tabular}{|c|c|c|c|c|c|c|c|c|c|c|}
\hline \multirow{2}{*}{$\begin{array}{l}\text { Time } \\
\text { Patient no. }\end{array}$} & \multicolumn{5}{|c|}{ Normals } & \multicolumn{5}{|c|}{ Diabetics } \\
\hline & 1 & 2 & 3 & 4 & 5 & $\overline{6}$ & 7 & 8 & 9 & 10 \\
\hline & 1.1 & 0.8 & 0.3 & 0.4 & 0.8 & 5.9 & 0.3 & 12 & 18 & 9.0 \\
\hline \multirow{2}{*}{9 a.m. } & 0.8 & 0.8 & 0.6 & 0 & 1.0 & 1.4 & 0 & $\overline{11}$ & 17 & 6.8 \\
\hline & 1.6 & 0.7 & 0.4 & 0 & 1.0 & 0.2 & 5.1 & 5.6 & 17 & 9.0 \\
\hline \multirow[t]{2}{*}{10} & 0.6 & 0.7 & 0.7 & 0 & 0.4 & 0.3 & 3.6 & 18 & 7.6 & 8.0 \\
\hline & 0.4 & 0.6 & 0.6 & 0 & 0.9 & 7.2 & 0 & 5.2 & 6.6 & 7.4 \\
\hline \multirow[t]{2}{*}{11} & 0.8 & 0.6 & 0.8 & 0 & 4.6 & 1.0 & 1.8 & 3.7 & 12 & 4.6 \\
\hline & 0.6 & 0.9 & 0.7 & 0 & 2.3 & 1.4 & 4.8 & 3.0 & 18 & 7.2 \\
\hline \multirow[t]{2}{*}{12} & 0.6 & 0.4 & 0.3 & 0.2 & 0.5 & 2.3 & 0.2 & 3.2 & 19 & 20 \\
\hline & 1.3 & 0.2 & 0.2 & 0 & 0.7 & 2.8 & 0.2 & 1.6 & 11 & 2.0 \\
\hline \multirow[t]{2}{*}{1 p.m. } & 0.8 & 0.4 & 0.8 & 0 & 0 & 1.0 & 0 & 2.0 & 7.2 & 3.0 \\
\hline & 0.8 & 1.2 & 0.8 & 0.4 & 0 & 0.8 & & 1.3 & 10 & 3.0 \\
\hline \multirow[t]{2}{*}{2} & 0.5 & 0.8 & 0.6 & 0 & 0.1 & 5.0 & 0.8 & 1.5 & 9.0 & 7.4 \\
\hline & 0.4 & 0.2 & & 0.4 & 0.5 & 8.0 & 0.5 & 1.8 & 5.8 & 4.8 \\
\hline \multirow[t]{2}{*}{3} & 1.0 & 0.8 & 0.6 & 0 & 0 & 1.4 & 0.1 & 3.1 & 5.6 & 8.6 \\
\hline & 0.8 & 0.5 & 0.3 & 0 & 0.1 & 0.5 & 0 & 4.3 & 5.4 & 9.0 \\
\hline \multirow[t]{2}{*}{4} & 1.6 & 0.4 & 0.8 & 0.2 & 0.4 & 0.5 & 5.2 & 19 & 3.4 & 3.8 \\
\hline & 1.0 & 0.4 & 0.6 & 0 & 5.6 & 0.5 & 2.0 & 4.0 & 6.6 & 7.0 \\
\hline \multirow{2}{*}{5} & & 0.4 & 3.2 & 0 & 7.4 & 0.6 & 0.1 & 2.7 & 13 & 19 \\
\hline & 0.7 & 0.6 & 14 & 0.5 & 2.3 & 0.1 & & 3.7 & 11 & 3.2 \\
\hline \multirow[t]{2}{*}{6} & & 1.0 & 2.8 & 1.1 & 0.5 & & 0 & 1.1 & 10 & 3.5 \\
\hline & 0.6 & 0 & 0.6 & 0 & 0.2 & 1.4 & 0 & 1.6 & 11 & 5.6 \\
\hline \multirow[t]{2}{*}{7} & 0.9 & 0.4 & 0.5 & 0.7 & 0.6 & 4.9 & 0 & 1.1 & 24 & 10 \\
\hline & 0.4 & 0.4 & 0.3 & 0.3 & 0.3 & 2.4 & 0 & 3.4 & 21 & 12 \\
\hline \multirow[t]{2}{*}{8} & 1.1 & 0.6 & 0.7 & 0 & 0.6 & 1.3 & 0 & 3.5 & 19 & 17 \\
\hline & 0.2 & 0 & 0.6 & 0 & 0.8 & 0.8 & 6.6 & 12 & 14 & 2.2 \\
\hline \multirow[t]{2}{*}{9} & 1.5 & 0.6 & 0.5 & 0.5 & 0.3 & 0.5 & 5.0 & 6.0 & 12 & 4.5 \\
\hline & 1.8 & 0 & 0 & 1.0 & 0.5 & 2.1 & 3.0 & 4.7 & 43 & 4.0 \\
\hline \multirow[t]{2}{*}{10} & 1.4 & 0.5 & 0.5 & 18 & 1.6 & 0.8 & 7.1 & 11 & 14 & 5.0 \\
\hline & 9.2 & 14 & 5.4 & 15 & 2.2 & & 15 & 7.3 & 13 & 6.2 \\
\hline \multirow[t]{2}{*}{11} & 6.6 & 14 & 4.3 & 7.3 & 1.8 & & 3,8 & 3.2 & 19 & 6.2 \\
\hline & 4.8 & 4.4 & 1.5 & 2.6 & 2.7 & & 3.1 & 2.8 & 12 & 3.4 \\
\hline 12 & 1.9 & 2.1 & 1.1 & 1.8 & 3.0 & & 0.2 & 3.0 & 8.4 & 13 \\
\hline & 1.1 & 0.9 & 0.8 & 1.9 & 1.5 & & 0 & 12 & 14 & 7.4 \\
\hline $1 \mathrm{a} . \mathrm{m}$. & 1.3 & 1.4 & 1.5 & 0.8 & 3.1 & & 1.9 & 13 & 14 & 6.8 \\
\hline & 15 & 9.5 & 13 & 3.6 & 13 & & 10 & 19 & 34 & 5.4 \\
\hline 2 & 8.4 & 5.5 & 6.0 & 3.1 & 7.2 & & 29 & 11 & 24 & 10 \\
\hline & 3.0 & 5.6 & 3.5 & 2.2 & 4.1 & & 14 & 5.4 & 22 & 11 \\
\hline 3 & 5.0 & 2.3 & 2.9 & 2.8 & 2.7 & & 17 & 4.3 & 24 & 25 \\
\hline & 1.8 & & 2.4 & 2.6 & 3.0 & & 12 & 4.0 & 15 & 12 \\
\hline 4 & 1.1 & 1.3 & 2.7 & 2.8 & 3.4 & & 1.6 & 2.8 & 14 & 12 \\
\hline & 1.0 & 1.8 & 2.0 & 1.0 & 3.4 & & 1.5 & 5.3 & 11 & 7.4 \\
\hline 5 & 1.3 & & 1.1 & 1.6 & 2.7 & & 1.4 & 2.8 & 12 & 9.5 \\
\hline & 0.8 & 4.3 & 0.8 & 1.6 & 1.6 & & 0 & 2.9 & 6.5 & 7.0 \\
\hline 6 & 1.5 & 0.1 & 2.4 & 2.0 & 2.0 & & 0 & 3.6 & 3.6 & 16 \\
\hline & 1.4 & 0.4 & 0.7 & 1.6 & 2.6 & & 0 & 29 & 10 & 12 \\
\hline 7 & 9.6 & 4.0 & 0.8 & 1.0 & 1.2 & & 0 & 9.3 & 7.8 & 12 \\
\hline & 9.6 & 0.6 & 1.5 & 1.7 & 1.6 & & 0 & 4.3 & 9.2 & 8.6 \\
\hline 8 & 2.0 & 0.6 & 2.5 & 0.7 & 1.6 & & 0 & 3.2 & 9.6 & 6.8 \\
\hline & 0.9 & 0.2 & 1.3 & 1.3 & 1.4 & & 0.3 & 2.6 & 12 & 3.8 \\
\hline
\end{tabular}

\section{Discussion}

This study has revealed the pattern of a series of parameters of importance in glucose homeostasis, as observed during a 24 -h period in young normal subjects and in young patients with recently discovered juvenile diabetes mellitus.

The variations in blood glucose were found to be as expected, both in the normals and in the diabetios. values showed little fluctuation with one puzzling exception. In two of the four juvenile diabetics a significant elevation of serum insulin was observed during and after the walk in the evening. The meaning of this phenomenon cannot be explained at the present time. However, recently one of us has found a statistically significant rise in serum insulin immediately after ergometer exercise in untreated, juvenile diabetics [8]. 
The 24-h pattern of serum glucagon has not been studied before. In the present study the concentration was found to be fairly constant during day and night in nondiabetics. No discernible rise could be seen in relation to food intake in either diabetics or non-diabetics. It is known [18] that large amounts of glucose directed) that they cannot be recognized in peripheral venous blood.

In the non-diabetic subjects growth hormone peaks only occurred $3-4 \mathrm{~h}$ or more after meals, and only when blood glucose and serum insulin had returned to fasting level. Although no correlation can be seen in

Table 4. The 24-h level of blood glucose, serum insulin, -glucagon and -free fatty acids in

\begin{tabular}{|c|c|c|c|c|c|c|c|c|}
\hline \multirow[t]{2}{*}{ Time } & \multicolumn{2}{|c|}{$\begin{array}{l}\text { Glucose } \\
\mathrm{mg} / 100 \mathrm{ml}\end{array}$} & \multicolumn{2}{|c|}{$\begin{array}{l}\text { Insulin } \\
\mu \mathrm{U} / \mathrm{ml}\end{array}$} & \multicolumn{2}{|c|}{$\begin{array}{l}\text { Glucagon } \\
\mathrm{ng} / \mathrm{ml}\end{array}$} & \multicolumn{2}{|c|}{$\begin{array}{l}\text { Free fatty acids } \\
\mu \mathrm{Eq} / \mathrm{l}\end{array}$} \\
\hline & Mean & S.E.M. & Mea & n S.E.M. & Mean & S.E.M. & Mean & S.E.M. \\
\hline & 198 & 23.2 & 6 & 1.6 & 0.6 & 0.05 & 980 & 220 \\
\hline \multirow{2}{*}{9 a.m. } & 192 & 15.8 & 6 & 1.7 & 0.6 & 0.10 & 610 & 138 \\
\hline & 284 & 22.2 & 5 & 1.4 & 0.6 & 0.00 & 730 & 190 \\
\hline \multirow[t]{2}{*}{10} & 333 & 20.0 & 5 & 2.4 & 0.6 & 0.05 & 720 & 171 \\
\hline & 343 & 16.2 & 6 & 1.7 & 0.5 & 0.00 & 800 & 190 \\
\hline \multirow[t]{2}{*}{11} & 365 & 27.2 & 7 & 2.4 & 0.5 & 0.00 & 760 & 205 \\
\hline & 367 & 33.9 & 6 & 1.8 & 0.5 & 0.00 & 780 & 203 \\
\hline \multirow[t]{2}{*}{12} & 358 & 27.2 & 5 & 1.7 & 0.4 & 0.00 & 780 & 215 \\
\hline & 359 & 34.2 & 9 & 1.3 & 0.7 & 0.00 & 770 & 185 \\
\hline \multirow[t]{2}{*}{1 p.m. } & 390 & 31.3 & 9 & 2.2 & 0.6 & 0.05 & 830 & 197 \\
\hline & 383 & 37.3 & 9 & 1.6 & 0.4 & 0.00 & 690 & 188 \\
\hline \multirow[t]{2}{*}{2} & 385 & 44.7 & 8 & 1.2 & 0.4 & 0.10 & 660 & 184 \\
\hline & 348 & 48.5 & 8 & 1.9 & 0.5 & 0.20 & 720 & 214 \\
\hline \multirow[t]{2}{*}{3} & 340 & 38.6 & 7 & 1.7 & 0.6 & 0.05 & 580 & 171 \\
\hline & 312 & 34.9 & 8 & 2.2 & 0.5 & 0.00 & 660 & 194 \\
\hline \multirow[t]{2}{*}{4} & 295 & 24.7 & 6 & 0.5 & 0.3 & 0.13 & 990 & 276 \\
\hline & 300 & 24.1 & 9 & 1.7 & 0.4 & 0.15 & 870 & 220 \\
\hline \multirow[t]{2}{*}{5} & 265 & 25.1 & 6 & 1.2 & 0.4 & 0.10 & 940 & 265 \\
\hline & 278 & 31.9 & 9 & 0.9 & 0.4 & 0.00 & 1030 & 285 \\
\hline \multirow[t]{2}{*}{6} & 280 & 31.5 & 7 & 0.6 & 0.4 & 0.10 & 970 & 166 \\
\hline & 336 & 30.4 & 5 & 1.5 & 0.3 & 0.05 & 820 & 130 \\
\hline \multirow[t]{2}{*}{7} & 373 & 43.4 & 6 & 1.3 & 0.3 & 0.15 & 790 & 160 \\
\hline & 393 & 39.1 & 9 & 1.6 & 0.3 & 0.05 & 780 & 244 \\
\hline \multirow[t]{2}{*}{8} & 377 & 31.4 & 8 & 2.4 & 0.3 & 0.20 & 830 & 223 \\
\hline & 349 & 30.7 & 7 & 1.7 & 0.3 & 0.00 & 820 & 192 \\
\hline \multirow[t]{2}{*}{9} & 353 & 26.8 & 6 & 2.3 & 0.1 & 0.05 & 1130 & 263 \\
\hline & 340 & 27.6 & 13 & 6.1 & 0.1 & 0.03 & 1010 & 228 \\
\hline \multirow[t]{2}{*}{10} & 328 & 26.8 & 20 & 11.6 & 0.4 & 0.25 & 830 & 210 \\
\hline & 303 & 21.0 & 9 & 5.3 & 0.1 & 0.10 & 650 & 145 \\
\hline 11 & 303 & 30.2 & 7 & 2.5 & 0.2 & 0.15 & 680 & 204 \\
\hline & 299 & 32.8 & 6 & 1.5 & 0.3 & 0.15 & 830 & 283 \\
\hline 12 & 291 & 26.1 & 5 & 1.7 & 0.2 & 0.15 & 810 & 197 \\
\hline & 279 & 21.0 & 4 & 2.4 & 0.1 & 0.00 & 820 & 258 \\
\hline $1 \mathrm{a} . \mathrm{m}$. & 266 & 18.2 & 4 & 2.1 & 0.2 & 0.15 & 700 & 169 \\
\hline & 259 & 15.0 & 5 & 2.0 & 0.2 & 0.10 & 610 & 108 \\
\hline 2 & 250 & 11.3 & 5 & 2.3 & 0.1 & 0.10 & 650 & 156 \\
\hline & 248 & 11.3 & 4 & 1.9 & 0.2 & 0.10 & 600 & 110 \\
\hline 3 & 244 & 8.8 & 5 & 3.0 & 0.2 & 0.05 & 630 & 155 \\
\hline & 239 & 9.0 & 4 & 1.6 & 0.1 & 0.05 & 650 & 196 \\
\hline 4 & 236 & 9.3 & 4 & 1.6 & 0.1 & 0.05 & 820 & 294 \\
\hline & 235 & 8.6 & 4 & 1.5 & 0.2 & 0.10 & 710 & 107 \\
\hline 5 & 233 & 9.2 & 4 & 1.8 & 0.2 & 0.05 & 670 & 107 \\
\hline & 233 & 11.1 & 4 & 1.9 & 0.2 & 0.05 & 640 & 125 \\
\hline 6 & 232 & 10.9 & 4 & 2.2 & 0.1 & 0.00 & 630 & 113 \\
\hline & 229 & 12.4 & 5 & 2.2 & 0.3 & 0.00 & 750 & 185 \\
\hline 7 & 232 & 14.2 & 5 & 2.5 & 0.1 & 0.00 & 590 & 129 \\
\hline & 232 & 15.1 & 3 & 1.9 & 0.2 & 0.05 & 770 & 145 \\
\hline 8 & 231 & 13.0 & 4 & 1.9 & 0.2 & 0.05 & 920 & 280 \\
\hline & 230 & 11.1 & 4 & 2.2 & 0.3 & 0.05 & 850 & 246 \\
\hline
\end{tabular}

$(100-200 \mathrm{~g})$ ingested orally can produce a rise in serum glucagon. Our meals contained 65, 44 and $123 \mathrm{~g}$ carbohydrate in a less readily absorbable form than a pure glucose solution. It thus seems that the alterations in serum pancreatic and gut glucagon which possibly occur during daily life are so small (or oppositely the 24-h pattern between the blood glucose level and the level of the serum growth hormone, a role for growth hormone in blood glucose homeostasis cannot be excluded. It is possible that growth hormone prevents blood glucose from falling to hypoglycaemic levels. Nine of the eleven growth hormone peaks 
occurred during the evening and in the night in the nondiabetics.

Our results confirm the earlier reports $[6,9,10,11$, $12,17,19]$ that serum growth hormone is depressed by food intake during the day, and also that during the night growth hormone is secreted in intermittent bursts.

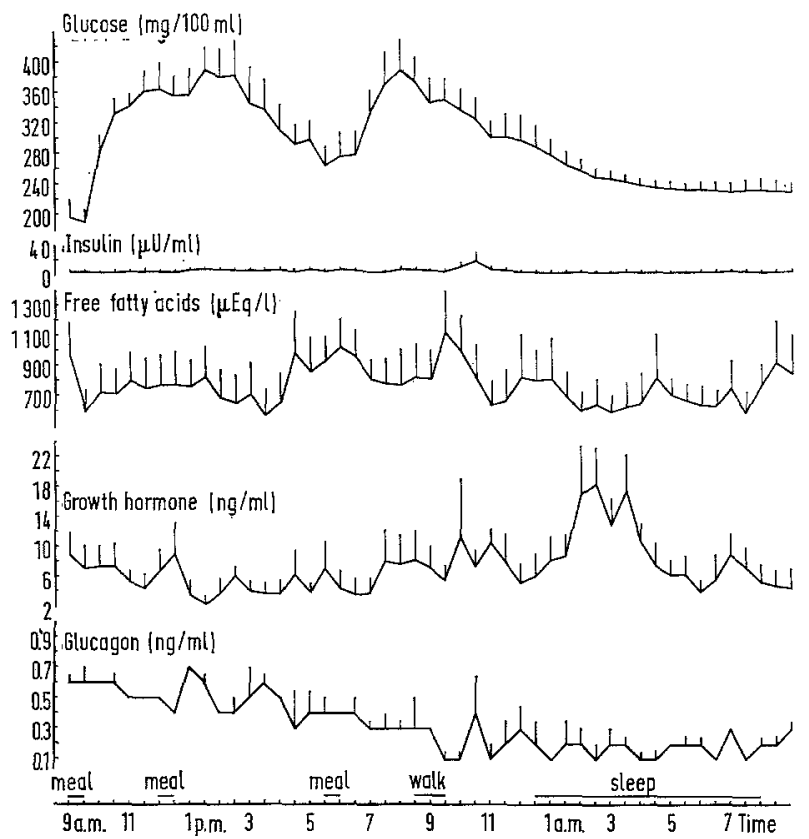

Fig. 3. Average curves of blood glucose, serum insulin, -free fatty acids, -growth hormone and -glucagon in five newly diagnosed, untreated male patients with classic juvenile diabetes. Mean values + S.E.M.

However, they do not contribute to the problem of a possible relationship between growth hormone peaks and the depth of sleep.

The well-known rebound of serum free fatty acids 4 $6 \mathrm{~h}$ after oral ingestion of glucose has been attributed to the late rise in growth hormone secretion. Our findings in the non-diabetics are not compatible with this suggestion, because the rises in free fatty acid in the late noon and the evening were not preceeded by growth hormone pealss. However, growth hormone could play a role in maintaining the high free fatty acid level during the night. In other experiments [16], we have found that the late rise in free fatty acids and growth hormone after oral glucose in healthy males was related. to the amount of glucose ingested, i.e. the greater the amount of glucose ingested the later the rise in growth hormone and free fatty acids will occur. In female subjects the same relationship between glucose ingestion and the free fatty acid rise was seen, but the growth hormone pattern was disrupted by sudden high growth hormone peaks, distributed throughout the six-hour period. These findings in the female subjects are also incompatible with the concept that a rise in growth hormone is responsible for the free fatty acid release. Quabbe et al. [17] also failed to find support for the idea of growth-hormone-induced release of free fatty acids during normal life. A connection between the high level of growth hormone and free fatty acids in the juvenile diabetics cannot, however, be ruled out.

The most interesting result obtained in the present study was the finding that the blood of male, non-obese

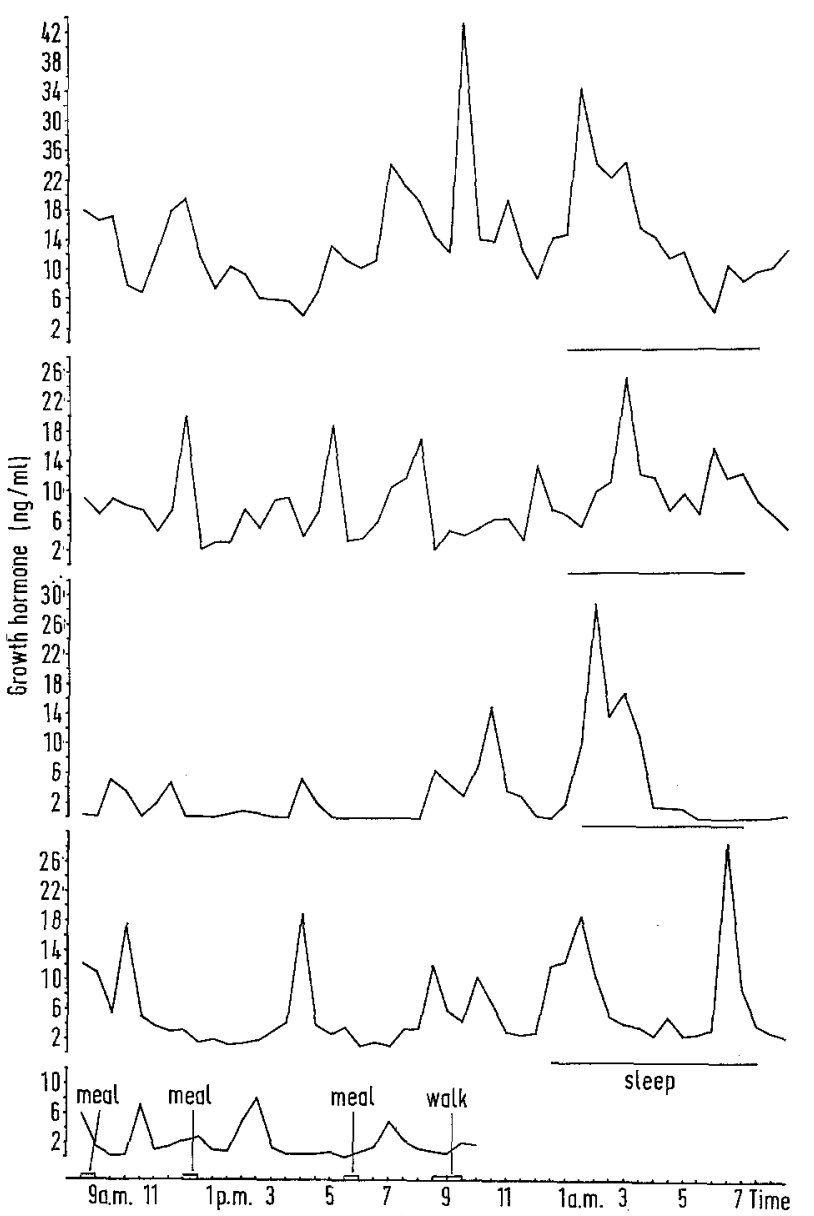

Fig. 4. The 24-h serum growth hormone level in five newly diagnosed, untreated male patients with classic juvenile diabetes

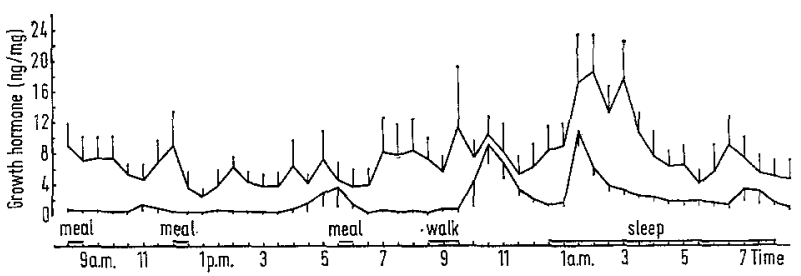

Fig. 5. Average curves of serum growth hormone in the five diabetics (upper curve) and in the five healthy subjects (lower curve). Mean values \pm S.E.M.

patients with recently discovered, untreated, classic juvenile diabetes contains much more growth hormone than that of non-diabetics, and that the level fluctuates much more wildly.

The high level of growth hormone could be the result of a higher secretion rate or of a lower disappear- 
ance rate. However, the diurnal growth hormone pattern, marked by numerous peaks makes the former alternative much more likely. The abnormal diurnal serum growth hormone pattern in untreated, juvenile diabetics could be an expression of high growth hormone secretion playing a role in the initiation of diabetes mellitus, as suggested by Young [23], or it could be a consequence of the metabolic derangement. Studies of the 24-h pattern in juvenile diabetes after normalization of the blood sugar and in pre-diabetics, are in progress to elucidate this problem.

Other abnormalities of serum growth hormone have been reported in pre-diabetics and diabetics. Prediabetics show a hyper-response to oral and intravenous glucose and to intravenous tolbutamide $[1,20]$. An abnormal, early rise in plasma growth hormone $21 / 2$ hours after ingestion of $100 \mathrm{~g}$ of glucose has been found by Yde [22]. One of us [8] has found significantly elevated fasting growth hormone values, and an excessively high growth hormone response to exercise in male non-obese patients with recently discovered classic juvenile diabetes, before as well as after normalization of the blood glucose levels. Burday [2] observed a failure of hyperglycaemia to block arginineinduced growth hormone release in insulin-dependent diabetic patients.

The high and fluctuating values of growth hormone in normal women $[5,21,16]$, and the steady hypersecretion of growth hormone in acromegaly is a stumbling block to any hypothesis postulating a role of growth hormone in the aetiology of diabetes mellitus.

However, a hypersecretion of growth hormone, if it occurs before the outbreak of diabetes mellitus, may well be an additional aetiological factor, the major prerequisite being an inherited insufficiency of the beta-cells, as stressed recently by Luft and Cerasi [14]. And even if the growth hormone is not of aetiological importance, the high diurnal level of this insulinantagonistic hormone in established juvenile diabetes must in any case lay a further burden on the metabolism.

\section{References}

1. Boden, G., Soeldner, J.S., Gleason, R.E., Marble, A.: Elevated serum human growth hormone and decreased serum insulin in prodiabetic males after intravenous tolbutamide and glucose. J. clin. Invest. 47, 729-739 (1968).

2. Burday, S.Z., Fine, P.H., Shalch, D.S.: Growth hormone secretion in response to arginine infusion in normal and diabetic subjects: Relationship to blood glucose levels. J. Lab. clin. Med. 71, 897-911 (1968).

3. Christensen, N.J.: Notes on the glucose oxidase method. Scand. J. clin. Lab. Invest. 19, 379-384 (1967).

4. - Ørskov, H.: The relationship between endogenous serum insulin concentration and glucose uptake in the forearm muscles of nondiabetics. J. clin. Invest. 47, 1262-1268 (1968).

5. Frantz, A.G., Rabkin, M.T.: Effects of estrogen and sex difference on secretion of human growth hormone. J. clin. Endocr. 25, 1470-1480 (1965).

6. Glick, S.M., Goldsmith, S.: The physiology of growth hormone secretion. In: Growth hormone. Proceedings of the I International Symposium. Milan 1968, p. 84.

7. Hales, C.N., Randle, P.J.: Immunoassay of insulin with insulin-antibody precipitate. Biochem. J. 88, $137-146$ (1963).

8. Hansen, A.P.: To be published.

9. Honda, Y., Takahashi, K., Takahashi, S., Azumi, K., Irie, M., Sakuma, M., Tsushima, T., Shizuma, K.: Growth hormone secretion during nocturnal sleep in normal subjects. J. clin. Endocr. 29, 20-29 (1969).

10. Hunter, W.M., Friend, J.A.R., Strong, J.A.: The diurnal pattern of plasma growth hormone concentration in adults. J. Endocr. 34, 139-146 (1966).

11. - Rigal, W.M.: The diurnal pattern of plasma growth hormone concentration in children and adolescents. J. Endocr. 34, 147-153 (1966).

12. - Willoughby, J.M.T., Strong, J.A.: Plasma insulin and growth hormone during 22-hour fasts and after graded glucose loads in six healthy adults. J. Endocr. 40, 297-311 (1968).

13. Laurell, S., Tibbling, G.: Colorimetric micro-determination of free fatty acids in plasma. Clin chim. Acta 16, 57-62 (1967).

14. Luft, R., Cerasi, E.: Human growth hormone as a regulator of blood glucose concentration and as a diabetogenic substance. Diabetologia 4, 1-9 (1968).

15. Ørskov, H., Thomsen, H. G., Yde, H.: Wick chromatography for rapid and reliable immunoassay of insulin, glucagon and growth hormone. Nature 219, 193-195 (1968).

16. - Christensen, N.J., Hansen, A.P.: To be published.

17. Quabbe, H.J., Schilling, E., Helge, H.: Pattern of growth hormone secretion during a 24-hour fast in normal adults. J. clin. Endocr. 26, 1173-1177 (1966).

18. Samols, E., Tyler, J., Marri, G., Marks, V.: Stimulation of glucagon secretion by oral glucose. Lancet 1965 II, $1257-1259$.

19. Takahashi, Y., Kipnis, D.M., Daughaday, W.H.: Growth hormone secretion during sleep. J. clin. Invest. 47, 2079-2089 (1968).

20. Unger, R.H., Siperstein, M.D., Madison, L.L., Eisentraut, A.M., Whissen, N.: Apparent growth hormone hyperresponsiveness in prediabetes. J. Lab. clin. Med. 64, 1013 (1964) (Abstract).

21. - Eisentraut, A.M., Madison, L.L., Siperstein, M.D.: Fasting levels of growth hormone in men and women. Nature 205, 804 (1965).

22. Yde, H.: To be published.

23. Young, F.G.: The relationship of the anterior pituitary gland to carbohydrate metabolism. Brit. Med. J. 1939 II, 393-396.

Errata: The growth hormone values in Fig. 1 and Fig. 5 should be given in $\mathrm{ng} / \mathrm{ml}$, not in $\mathrm{ng} / \mathrm{mg}$.

Dr. Aa. P. Hansen

Second University Clinic

of Internal Medicine

Kommunehospitalet

Aarhus, Denmark 